\title{
ATTITUDES OF HIGH-LEVEL FEMALE SPRINTERS TOWARDS FACTORS INFLUENCING THE TRAINING SYSTEM
}

\author{
Lina Grinčikaitė-Samuolè \\ Lithuanian Sports University, Kaunas, Lithuania
}

\begin{abstract}
Background. Research conducted in the field of sports science has supported the idea that training high-level sprinters is a consistent process, covering development of not only physical abilities (Bompa \& Haff, 2009), but also a consistent personal development through the means of sports-related activity. For many years the prevalent opinion has claimed that success most often depends on the level of athletes' physical and tactical training; however, growing competition among the athletes calls for a deeper analysis and empirical substantiation in relation to factors influencing athlete training. Qualitative research results have demonstrated that high-level female sprinters prioritize athletic and technical training; however, there is a lack of attention to psychological, tactical and theorybased preparation. Obtained results have revealed that female runners are best motivated to excel, improve their performance by the external (cash prizes) rather than internal factors, the coach's authority also plays a significantly high role. The aim of research was to discuss factors, influencing the training system of high-level female sprinters.

Methods. Conducted qualitative research employed the semi-structured interview method. During the period from January to June of 2015, a total number of 20 best Lithuanian high-performance female sprinters of all time, dominating at the top of the World's and Europe's ratings, were interviewed.

Results. The obtained research results have demonstrated that in the course of their training process runners fail to concentrate on a significant component of their training - mental training, whereas athletic and technical training, according to the respondents, is integral, thus is a priority element of the sports-related training process. It was also revealed that high-performance female sprinters were far more motivated to excel and improve their results by the external rather than the internal factors. During the interview, the respondents mostly specified being satisfied with a reward, i.e. prizes, but not honour to represent the country, or despite the reward, willingness to improve their results. Personality of the coach is also a key component in the sports-related training among high-performance female sprinters. Data obtained during the interview showed that the coach was considered not only as a specialist, but also an integral part of the training process valued for the personal qualities, such as sincerity, friendliness, ability to motivate and encourage.

Conclusions. High-performance female sprinters fail to focus on a significant component of sports-related training process - psychological training. The results have demonstrated that the external factors rather than the internal ones influence their sports-related training and improvement of results. The coach is considered to be an integral part of the sports-related training process.
\end{abstract}

Keywords: high-performance, female sprinters, training system.

\section{INTRODUCTION}

$\mathrm{S}$ port, embracing a system of physical, spiritual and cultural education, achievements in sport, knowledge of the field, and international communication, is a value in every nation (Karoblis, 2005).
The training process of athletes is a continuous educational action of a specific content and organizational form which develops physical abilities of an athlete, determines his/her activity, behaviour, independence and a sense of responsibility, and 
promotes to excel. However, the greatest influence in improving the sports results still comes from optimization of athlete training technology, building of a training system and filling it with a worthy content (Bompa, 1999; Karoblis, 2005; Платонов, 2004).

High-level sport is inseparable from competitions and pursuit of sports results. (Hargreaves \& Macdonald, 2000; Karoblis, 2005). Special training of athletes within the limits of a chosen sport is part of the personality's general education, having a close relationship with social, educational, political, and economic questions of human evolution (Johnson, Delva, \& Malley, 2007). Research conducted in the field of sport science has supported the idea that training high-performance athletes is a consistent process, covering the development of not only physical abilities (Bompa \& Haff, 2009), but also a consistent personal development through the means of sports-related activity. For many years the prevalent opinion has claimed that success most often depends on athletes' physical fitness and tactical training; however, growing competition among athletes calls for a deeper analysis of other aspects, having influence on athletes' training.

The aim of research was to discuss factors influencing the training system of high-performance female sprinters.

\section{METHODS}

The qualitative research method, i.e. interview, was used to obtain the opinion-based information from high-level female sprinters on factors affecting their training system. The semi-structured questionnaire, which provokes the athletes to reflectively analyse their sport-related activity and its quality and answer the key questions: motives influencing the training of high-performance female sprinters, strong and weak features of the training system and training objectives. The following ethical standards during the interview have been complied with: all of the informants participated in the research on a voluntary basis; the researcher introduced them to the research aims; anonymity of the respondents and their shared information has been guaranteed.

Research methodology is based on a content analysis strategy - the researcher's numbered categories were divided into subcategories, which facilitated to reveal the respondents' opinions on the questions provided. Twenty best Lithuanian high performance female sprinters, dominating at the top of the World's and Europe's ratings, have been interviewed.

Data analysis. The qualitative research data analysis has been performed using the method of content analysis. Responses of high performance female sprinters were firstly processed using the content analysis method, where phrases and thoughts similar in their meaning were categorized and subcategorized. In other words, individual but similar in their content phrases, received a generalizing label called category, and subcategories specifying such categories in more detail allowed to detect the differences in respondents' attitudes toward the given question. Such analysis covers four steps (Žydžiūnaitè, 2003): 1. Multiple reading of the texts, 2. Identification of manifest categories based on key words, 3 . Subcategorization of the categories' content, and 4. Interpretation of categories and subcategories, their substantiation based on extracted phrases from the total data. This research procedure allowed to calculate the frequency of categories, which revealed the prevalence of individual attitudes and their combinations within the population being researched, i.e., allowed to reveal both the dominant and rare, atypical attitudes. It should be noted that the respondents during the interview could perceive and emphasize the most diverse aspects of a problem within the question provided, i.e. they were not given specific content related to the answer options. Theoretical position has been maintained claiming that the text provided by the female respondents is a material of content analysis as an educational diagnostics research, imaging a person's reflection process as a vital aspect of the experiential learning (Jonušaitè, Žydžiūnaite, \& Merkys, 2005).

\section{RESULTS}

Results obtained during the qualitative research revealed that achievement of set goals influenced the high performance female sprinters' training. Results are provided in Figure 1.

The category identified in Figure 1, which allows revealing the training objectives of high performance female sprinters, is specified by four subcategories highlighting that the principal and top priority training objectives of the interviewed female athletes. They are improvement of personal results and self-realization during the high-level competitions (European championship, World 
Figure 1. Principal training objectives of high performance female sprinters

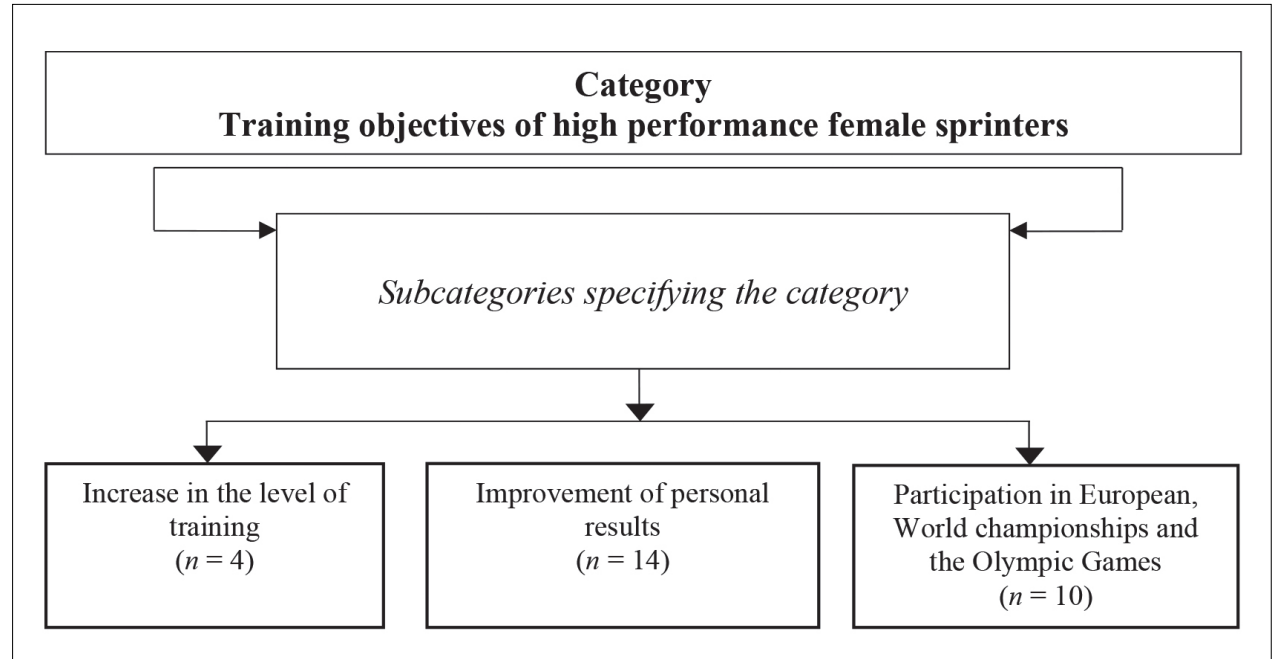

championship, the Olympic Games) <...the main purpose of my training in sport is to improve mypersonal result every year, record results at the major competitions...>, <...improve my results and fight for the top prizes...> . However, the survey revealed that an increase in the level of training, according to the respondents, was less important in the sportrelated training as the latter was regarded as an integral part of the sport-related educational process $<$...with an increasing excellence in sport the extent of physical load is automatically increased...>. The conducted research also revealed that motivation rather significantly influenced the implementation of goals. When pursuing to improve their results, their self-realization was increasing, which is an inseparable part of the sport-related training (Malinauskas, 2003; Ryan \& Deci, 2007), playing a significant role. The scientific literature divides motivation into internal and external. The internal motivation is willingness to be effective and act for the activity itself. In that case, athletes are driven by their internal pride, which works as their inner engine, stimulating them to achieve the best results even when there is no one to appreciate it or even notice (Malinauskas, 2003). The external motivation is a reward-driven aspiration. This type of motivation, contrary to the internal one, is determined by the external factors, such as a reward for achieved results, honour-based acknowledgment, negative or positive attitude of the society, support or lack of support, etc. Both types of motivation are prevalent among high performance female sprinters in their training process. Such information is substantiated by the results, obtained during the interview-based survey (Figure 2).

Results presented in Figure 2 are explained by the category and specifying subcategories focusing on the problem being researched. The data showed that three motives were the key influential factors in terms of high performance female sprinters' training and improvement in performance. The external top priority motive was monetary rewards $<$...prize money won during the competition ensures financial stability...>; <...money, which I use for sport camps, supplements, etc., allows me to get ready for the next season...> <...winning opens the opportunity to sign profitable contracts with the sports brands, which grant a financial support...> and the remaining two internal motives listed in the order of their importance were improvement of performance and pursuit to participate in the Olympic Games <...my main goal is to participate in the Olympic Games...>; <...desire to prove myself that I can be one of the best in Europe...>; $<. .$. wish to beat my 11 seconds running speed...>.

According to Mester, Perl and Hartmann (2000), Perl and Weber (2004), the level of athletes' fitness is influenced by the abundance of training indicators (athletic, technical, tactical, functional fitness, mental, theoretical) and the results of sprinting competitions depend on a level of physical, functional, technical and psychological training (Eikenberry et al., 2008; Guggenheimer, Dickin, Reyes \& Dolny, 2009; Hollings \& Robson, 1991; Kale, Asçi, Bayrak, \& Açikada, 2009; Linder et al., 2010; Stanislovaitis, Grūnovas, \& Butkus, 2006; Winchester, Nelson, Landin, Young \& Schexnayder, 2008; Young, McLean, \& Ardagna, 1995; Озолин, 1986; Табачник, 1988). Based on high performance female sprinters' interview extracts obtained during the conducted research, the strong and the weak features of sport-related training are discussed. Results are presented in Figure 3. 


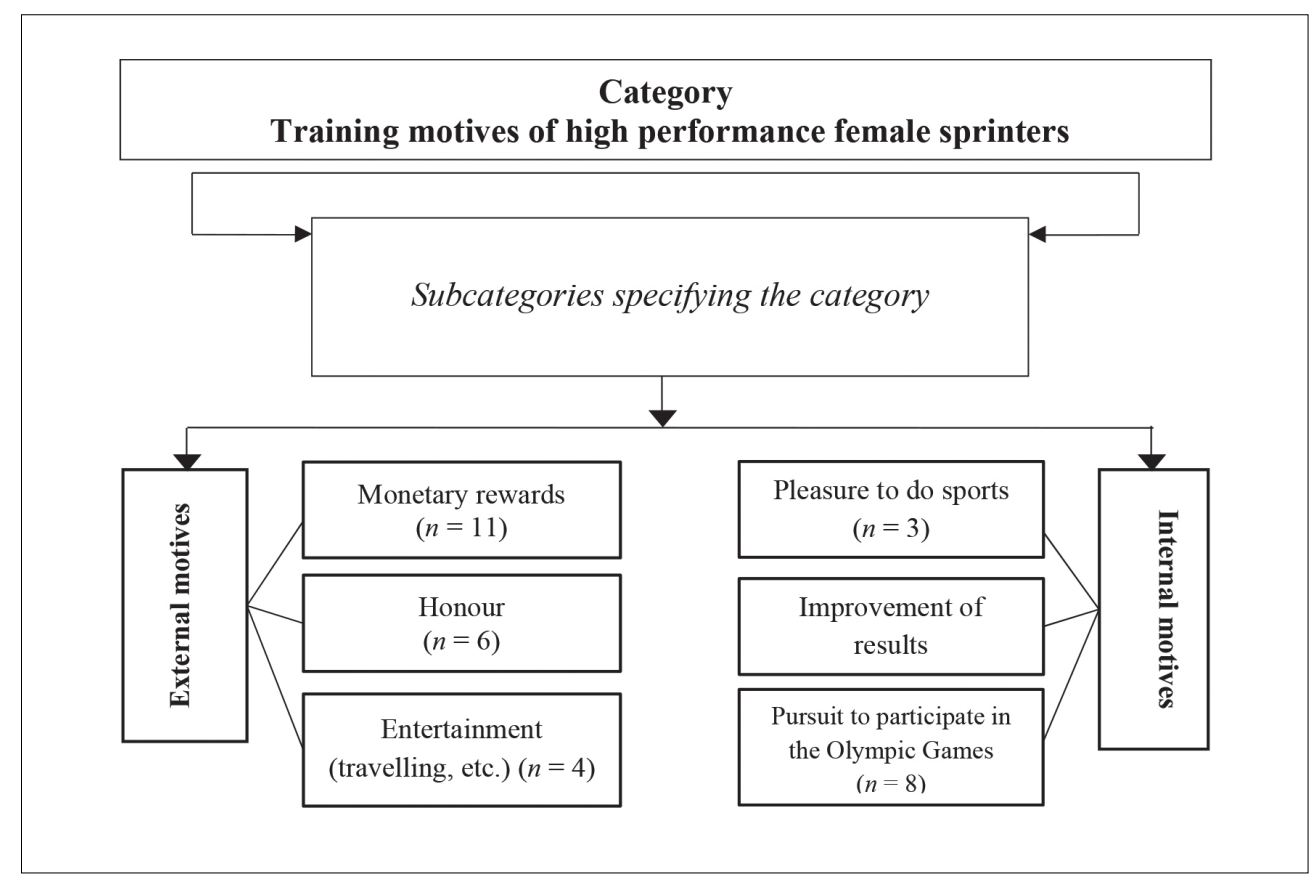

Figure 2. Motives influencing the training of high performance female sprinters

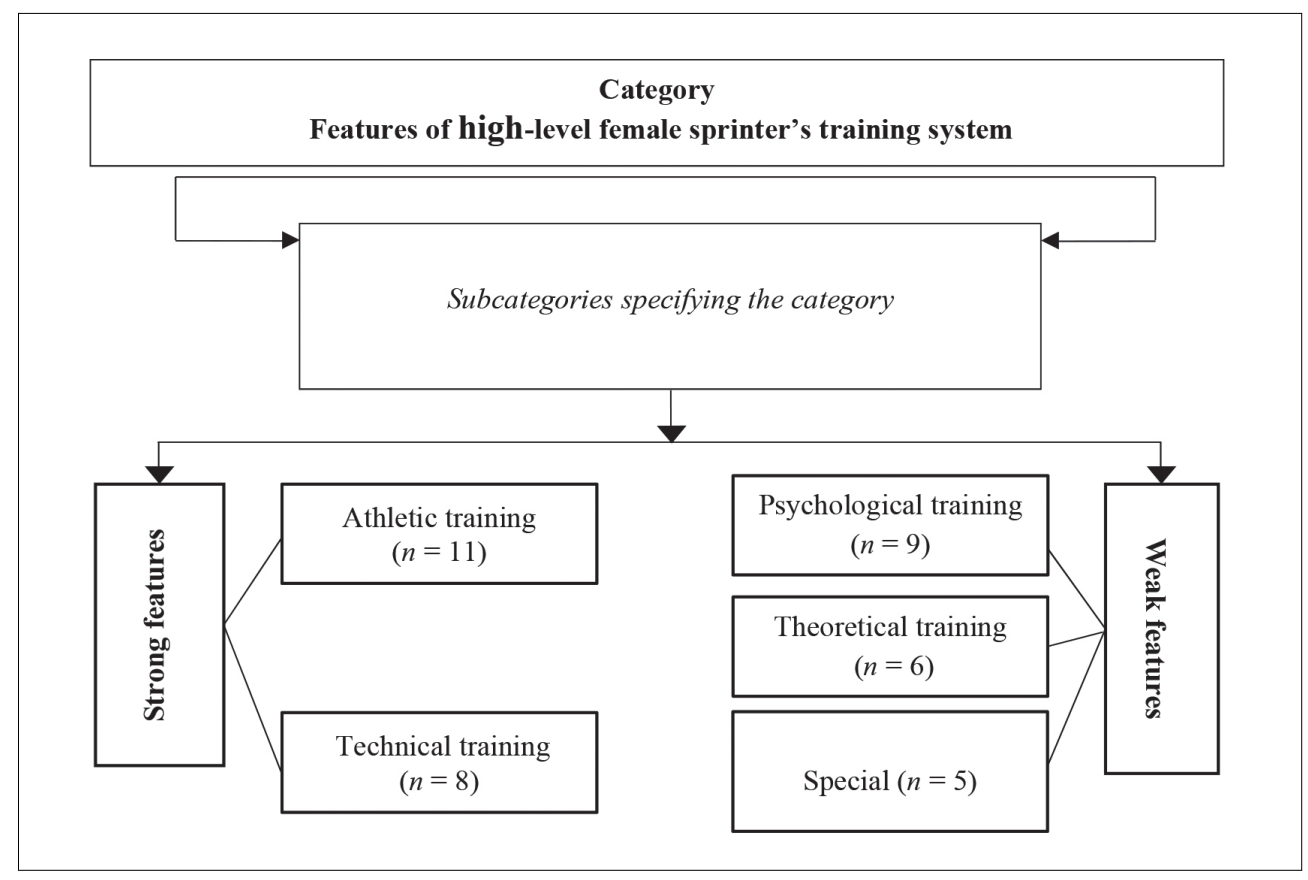

Figure 3. Strong and weak features of high performance female sprinters' training system

Category presented in Figure 3, labelled as features of high performance female sprinters' training system, is elaborated with two subcategories and the statements within them, substantiating the strong and weak features of the sport-related training. Based on the extracts from the interview, it should be noted that the informants prioritized athletic and technical readiness in the process of their sport-related training <...improvement of technique is constantly emphasized...>; <...we pay great attention to athletic fitness during the training process...>, which were considered to be the strong features, while the weak features were named as:

- Psychological training < ..during competitions I cannot cope with my nervousness, I get scared...>; <..."I burn out during competitions..." $>$; <...worrying does not allow me to realize myself to the fullest $>$, though Malinauskas (2003); Karoblis (1994) emphasize psychological fitness as a highly significant factor. Solid psychological preparation facilitates athletes to optimally use their physical 
and mental powers during the workouts and competitions, which in turn has positive influence on final results:

- tactical training is more dominant in the middle distance running < ...no tactics are involved in sprinting as the entire distance (e.g. $100-200 \mathrm{~m}$ ) is ran using maximum effort...>;

- theoretical training <...certain exercises, their effect, etc. are not given a theoretical reason...>.

Subjects involved in the training process of high performance athletes are the athletes themselves and their coach. Their relationship, attitude and motives form the basis for the personality formation and pursuit of sport-related results (Miškinis, 1998). Professional excellence of a coach, qualification, knowledge in special physiology, sport medicine, psychology, pedagogy, biochemistry and other sciences have the greatest influence in the process of sport-related training (Karoblis, 1994; Wilmore \& Costil, 1994). The role of a coach in the training process is evident from the results; it is presented in the Table.
Considering responses, presented in Table 1, gathered from the high performance female sprinters, it is evident that coach is regarded not only as a specialist, but also as an integral part of the training process with an emphasis placed on their personal qualities. The majority of the respondents valued their coach for constant encouragement and motivation $<\ldots$ the coach encourages to work consistently during the workouts... $>,<\ldots$ always motivates and compliments... $>$, while according to other athletes the coach was an authority figure $<\ldots I$ fully trust the coach, his words are final in making certain decisions. He is able to perfectly control the workout sessions, deal with the athletes.>, the remaining female sprinters appreciated the coach's sincere behaviour and friendliness $<\ldots$ friendly and kind...>, <.. helpful, gives sincere advice...> .

During the process of research it was interesting to learn what brings satisfaction to high performance female sprinters in their sporting career. Having reviewed the results presented in Figur 4, with a category labelled as satisfaction of high performance female sprinters

Table. Communication and cooperation of a coach and high performance female athletes

\begin{tabular}{|c|c|c|}
\hline Category & Subcategory & Substantiating statements (extracts from interview) \\
\hline \multirow{4}{*}{$\begin{array}{c}\text { Relationship } \\
\text { between a } \\
\text { coach and high } \\
\text { performance } \\
\text { female athletes in } \\
\text { sport }\end{array}$} & $\begin{array}{l}\text { Encouragement, motivation } \\
\qquad(n=8)\end{array}$ & $\begin{array}{l}<\ldots \text { the coach encourages to work consistently during the workouts... }>\text {, } \\
<\ldots \text { always motivates and compliments...>, <...encourages athletes, } \\
\text { compliments them during the workouts...>. }\end{array}$ \\
\hline & $\begin{array}{l}\text { Sincerity, friendliness } \\
\qquad(n=4)\end{array}$ & $<\ldots$ friendly and kind...>, <..helpful, gives sincere advice... $>$. \\
\hline & $\begin{array}{l}\text { Coach - authority figure } \\
\qquad(n=5)\end{array}$ & $\begin{array}{l}<\ldots \text { coach }- \text { authority figure... able to perfectly control the workout } \\
\text { sessions, deal with the athletes. }>\end{array}$ \\
\hline & $\begin{array}{l}\text { Psychological help } \\
\qquad(n=3)\end{array}$ & $\begin{array}{l}<\ldots \text { takes care of athletes' psychological state... }>,<\ldots \text { is able to handle } \\
\text { psychological issues... }>\text {. }\end{array}$ \\
\hline
\end{tabular}

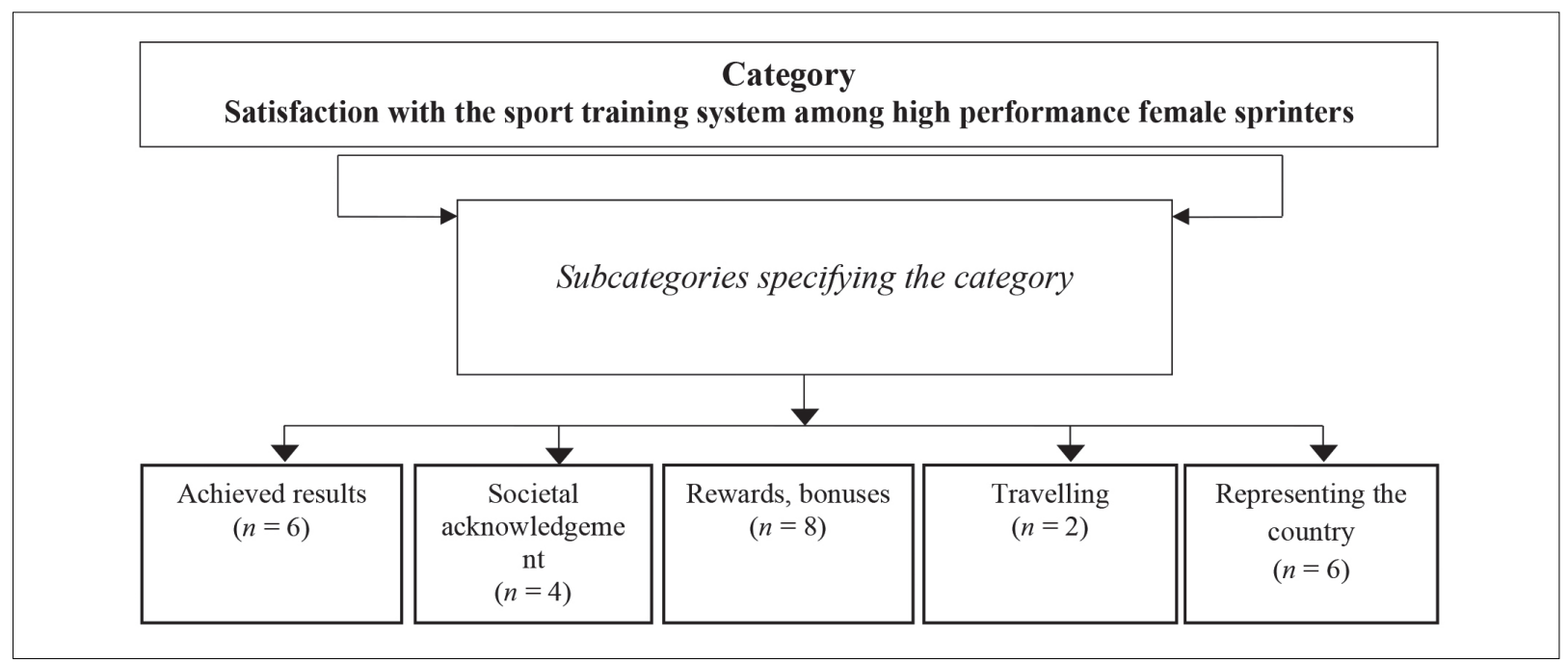

Figure 4. Aspects of satisfaction within the sporting career among high performance female sprinters 
with the sport-related training system and subcategories specifying the named category, the main satisfaction aspects were identified. It was established that the informants felt satisfied having received rewards and bonuses <...I feel appreciated having received a reward $>$; <...prizes stimulate to pursue a better result or improve one...>, while a lower number of respondents mentioned that they felt satisfaction not because of monetary rewards, but because of achieving a set goal and the honour to represent the country <...I feel proud of myself when I achieve desirable results $>$; <...standing on an award podium with the country's anthem is overwhelming, it forces to forget all the trouble...>.

\section{DISCUSSION}

According to the scientists (Doscher, 2009; Eikenberry et al., Guggenheimer et al., 2009; 2008; Hollings \& Robson 1991; Kale et al., 2009; Linder et al., 2010; Stanislovaitis et al., 2006; Winchester et al., 2008; Young et al., 1995; Озолин, 1986; Табачник, 1988), sprinting results depend on a level of physical, functional, technical and psychological training (Eynon et al., 2013). High performance female sprinters acknowledge this fact by prioritizing athletic and technical training, however, psychological training, according to the respondents, is a huge obstacle. Scientific literature (Malinauskas, 2003; Karoblis, 1994) emphasizes that psychological fitness is one of the key factors, facilitating athletes to optimally employ their physical and psychological powers during the workouts and competitions, which in turn has positive effect on a final result, thus, considering scientific observations, it is important to take into account not only the training of physical skills and technique, but psychological fitness.

Training for high performance female sprinters is a motive-driven process. The scientific literature divides motivation into internal and external motivation. The internal motivation is willingness to be effective and act for the activity itself. In that case, an athlete is driven by his internal pride, which works as his inner engine, stimulating the athlete to achieve the best results even when there is no one to appreciate it or notice (Malinauskas, 2003). The external motivation is a reward-driven aspiration. This type of motivation, contrary to the internal one, is determined by the external factors, such as a reward for achieved results, honour-based acknowledgment, negative or positive attitude of the society, support or lack of support and etc. It is emphasized that a high performance athlete should train driven by the internal motives. i.e., train out of the desire to improve performance without any reward, represent the country, etc. (Smith, 2013). However, very often athletes are driven by monetary prizes and rewards. Such statement is substantiated with the results obtained during the present research. It was established that the majority of the best Lithuanian female sprinters, dominating at the top World's and Europe's ratings, are more satisfied with the awards rather than honour to represent their country, or despite the reward, willingness to improve results.

Scientific literature observes that a coach along with their professional excellence, qualification, and knowledge in special physiology, sport medicine, psychology, pedagogy, biochemistry and other sciences (Mageau \& Vallerand, 2003) is a key in the training process of high performance female athletes. According to Mester et al. (2000) and Miškinis (1998), relationship between the coach and the athlete, attitude and motives form the basis for a personal development and achievement of results (Mester et al., 2000). For this reason, the present research shed some light on the contribution and a role of a coach in the training process of high performance female sprinters. Obtained results demonstrated that runners appreciated such personal qualities of their coach as sincerity and friendliness, according to them the coach helps in achieving better results by encouraging and motivating the athletes, thus is considered to be an integral part of the training process.

\section{CONCLUSIONS}

High performance female sprinters lack attention in the process of their training dedicated to a significant training component - psychological training. It was established that the external motives (monetary prizes, bonuses) rather than the internal ones (willingness to improve results, honour to represent the country) affected their training and improvement of performance. Personality of a coach was also a key influential factor. The coach was appreciated not only as a specialist, but also was considered to be an integral part of the training process by emphasizing such personal qualities as sincerity, friendliness, ability to motivate and encourage. 


\section{REFERENCES}

Bompa, T. O., \& Haff, G. (2009). Periodization: Theory and methodology of training. Champaign. IL: Human Kinetics.

Bompa, T. O. (1999). Periodization: Theory and methodology of training. USA: Human Kinetics.

Doscher, W. (2009). The art of sprinting: Techniques for speed and performance. North Carolina, USA: McFarland. Company Inc.

Eikenberry, A., McAuliffe, J., Timothy, N., Welsh, C. Z., McPherson, M., \& Newhouse, I. (2008). Starting with the "right" foot minimizes sprint start time. Acta Psychologica, 127(2), 495-500.

Eynon, N., Hanson, E. D., Lucia, A., Houweling, P. J., Garton, F., North, K. N., \& Bishop, D. J. (2013). Genes for elite power and sprint performance: ACTN3 leads the way. Sports Medicine, 43(9), 803-817.

Guggenheimer, J. D., Dickin, D. C., Reyes, G. F., \& Dolny, D. G. (2009). The effects of specific preconditioning activities on acute sprint performance. Journal of Strength and Conditioning Research, 23, 1135-1139. Hargreaves, J., \& Macdonald, I. (2000). Culture studies and the sociology of sport. In J. Coakley, E. Dunning, Handbook of Sports Studies (pp. 48-60). London: Sage.

Hollings, S. C., \& Robson, G. J. (1991). Body build and performance characteristics of male adolescent track and field athletes. The Journal of Sports Medicine and Physical Fitness, 31(1), 178-182.

Johnson, L., Delva, J., \& Malley, P. (2007). Sports participation and physical education in American secondary schools: Current levels and racial, ethnic and socioeconomic disparities. American Journal of Preventive Medicine, 33(4), 195-218.

Jonušaitė, S., Žydžiūnaitè, V., \& Merkys, G. (2005). Socialinio pedagogo adaptacijos kokybinè diagnostika. Pedagogika, 76, 23-32.

Kale, M., Asçi, A., Bayrak, C., \& Açikada, C. (2009). Relationships among jumping performances and sprint parameters during maximum speed phase in sprinters. The Journal of Strength and Conditioning Research, 23(8), 2272-2279. doi: 10.1519/JSC.0b013e3181b3e182 Karoblis, P. (1994). Sportinès treniruotès struktūra ir valdymas. Vilnius: LSIC.

Karoblis, P. (2005). Sportinio rengimo teorija ir didaktika. Vilnius: Infoastras.

Linder, E. E., Prins, J. H., Murata, N. M., Derenne, C., Morgan, C. F., \& Solomon, J. R. (2010). Effects of preload 4 repetition maximum on $100 \mathrm{~m}$ sprint times in collegiate women. The Journal of Strength and Conditioning Research, 24(5), 1184-1190.
Mageau, G. A., \& Vallerand, R. J. (2003). The coachathlete relationship: A motivational model. Journal of sports science, 21(11), 883-904.

Malinauskas, R. (2003). Didelio meistriškumo dvikovès sporto šakų sportininkų ir jų rezervo motyvacijos ypatumai. Sporto mokslas, 1(31), 19-23.

Mester, J., Perl, J., Niessen, M., \& Hartmann, U. (2000). Time series analyses and metamodels for analyses of physiological adaptation. In J. Avela, P. V. Komi, J. Komulainen, Proceedings of the 5th Annual Congress of the European College of Sport Science (p. 75). Jyväskulä: University of Jyväskulä:

Miškinis, K. (1998). Trenerio etika. Kaunas: Šviesa.

Perl, J., \& Weber, K. (2004). A Neural Network approach to pattern learning in sport. International Journal of Computer Science in Sport, 3(1), 67-70.

Ryan, R. M., \& Deci, E. L. (2007). Active human nature: Self- determination theory and the promotion and maintenance of sport, exercise, and health. In M. S. Hagger, N. L. D. Chatzisarantis (Eds.), Intrinsic motivation and self-determination in exercise and sport (pp. 1-19). London: Human Kinetics Europe Ltd.

Smith, A. R. (2013). A six week modified sprint interval training program incorporating extended exercise bouts does not increase maximal cardiac output (Doctoral dissertation, Electronic Thesis and Dissertation Repository, Paper 1707). Retrieved from http://ir.lib.uwo.ca/etd/1707. Stanislovaitis, A., Grūnovas, A., \& Butkus, V. (2006). Trumpuju nuotoliu begimas. Kaunas: LKKA.

Wilmore, J. H., \& Costill, D. L. (1994). Physiology of Exercise and Sport. Champaign, IL: Human Kinetics.

Winchester, J. B., Nelson, A. G., Landin, D., Young, M. A., \& Schexnayder, I. C. (2008). Static stretching impairs sprint performance in collegiate track and field athletes. The Journal of Strength and Conditioning Research, 22(1), 13-19.

Young, W., McLean, B., \& Ardagna, J. (1995). Relationship between strength qualities and sprinting performance. The Journal of Sports Medicine and Physical Fitness, 35(1), 13-19.

Žydžiūnaitė, V. (2003). Komandinio darbo kompetenciju edukacine diagnostika ir ju vystymo, rengiant slaugytojus, pagrindimas (daktaro disertacija: socialiniai mokslai, edukologija). Kaunas: KTU

Озолин, Э. С. (1986). Спринтерски бег. Москва: ФиС. Платонов, В. Н. (2004). Система подготовки спортсменов в олимпическом спорте. В книге Общая теоря и её практические приложения. Киев: Олимпийская литература.

Табачник, Б. (1988). Спринтерский бег. Легкая атлетика, 5, 18-20. 